\title{
OBSERVATIONS ON THE CONCEPT OF THE AQUAPELAGO OCCASIONED BY RESEARCHING THE MALDIVES
}

[Received January 2nd 2017; accepted January 21st 2017- DOI: 10.21463/shima.11.1.05]

\section{Lindsay Bremner}

University of Westminster <l.bremner@westminster.ac.uk>

\begin{abstract}
In my recent work on the Maldives (Bremner, 2016), I drew on Hayward's notion of the aquapelago (Hayward 2012a, 2012b) to theorise the Maldives and to develop a new metageographical concept for architecture in today's globalised world. In this short contribution to Shima debates, I will highlight my observations on the Maldives and the concept of the aquapelago occasioned by this work.
\end{abstract}

KEYWORDS: aquapelago, performativity, amphibious history, the Maldives

Introduction

Hayward (2012a) proposed the term aquapelago to describe regions in which aquatic spaces play a vital constitutive role in social and cultural life, and where the term archipelago, too heavily associated with its islands, proves of limited use. In my work on the Maldives, a territory comprised mostly of ocean ( $99.66 \%$ to be precise) and where geography, economics, politics and culture is continuously animated by or in relation to the sea, I found this term particularly helpful. It offered a new frame through which to extend the "amphibious history" of the Indian Ocean (Pearson, 2003: 5). Hayward used the term to describe "an assemblage of the marine and land spaces of a group of islands and their adjacent waters" (2012a: 4) and to advance the idea that these environments are generated or performed into being by "human (inter)activity" (2012b: 2). This drew on earlier work of Pacific Ocean scholars, who conceptualised Oceana as "a sea of islands with their inhabitants" rather than as "small areas of land sitting atop submerged reefs or seamounts" (Hau'ofa, 1993: 8). Aquapelagic assemblages, are "performed entities" (Hayward, 2012a: 6), generated by changing climate patterns, trading systems, socio-economic relations, and technologies etc. Hayward later went further to propose that the "actants" (Latour, 2004: 237) that perform an aquapelago are not only human, but include the animate (biological), inanimate (geological) and energetic forces that animate an aquapelagic environment: "The air above the waters and land, the weather that occurs in it, the windblown seeds and species than are born by it and the birds than inhabit the air, sea and land are just as much part of the integrated space of the aquapelago" (Hayward, 2012b: 2). It was this expanded idea of the aquapelago as space performed into being by the interactions between many different species of terra-aqueous actants that my work on the Maldives was drawn to. It enabled me to make connections, across multiple scales and temporalities, between human performativity and the non-human species, geological processes and earth system energies continuously interacting to bring the Maldives into being.

Shima <www.shimajournal.org> ISSN: 1834-6057 


\section{A Coral Aquapelago}

In the 1990s seismic studies undertaken as part of an oil-drilling program in the Maldives showed that its atolls were built on a volcanic ridge that stretched from a hotspot beneath the island of Reunion to the Deccan Traps of India (Naseer, 2006). This ridge had erupted as the Indian subcontinent underwent its tectonic drift northwards from around 67 megaannum (Ma) ago, forming a line of volcanoes that today constitutes the undersea ChagosLaccadives Plateau. When the Indian subcontinent met the Asian plate, it slowed down and the volcanoes slowly subsided into the sea, leaving fringes of upwardly growing coral reefs that built up over centuries to form atolls. Today atoll rims surround coral-floored basins 25-50 $\mathrm{m}$ deep rising towards their edges and dropping off steeply to the surrounding ocean floor to depths of 2500-4000 m (Naylor, 2015). The tops of these cones mark the ancient fringes of now submerged volcanic peaks to form the slender corridor of twenty-six atolls that make up the Maldives (Figure 1).

It was Charles Darwin (1842) who first proposed that coral reefs "although plainly geological structures on a stupendous scale, were created by slow, gradual growth of countless billions of tiny creatures over vast periods of time" (Chancellor, 2008). They are formations of calcium carbonate $\left(\mathrm{CaCO}_{3}\right)$ secreted by oceanic organisms called polyps in a metabolic relationship with a species of photosynthetic algae called zooxanthellae that live in their tissue. This relationship only survives in balmy oceanic environments of $18-29^{\circ} \mathrm{C}$ and only to depths of $45 \mathrm{~m}$ below sea level. Today however, these conditions are threatened by local development and changing global climates (Intergovernmental Panel on Climate Change, 2001). After tourism and associated industries began to transform the Maldivian economy in the 1970s, relations within the ocean ecosystem were dramatically altered (Naseer, 1997). Waste discharges, pollution, dredging, reclamation, construction of maritime structures, increased recreational diving and so forth produced changes in ocean chemistry and turbidity. Nutrient cycles between polyps and algae began to break down and polyps became physically stressed and expelled their resident algae. This resulted in coral bleaching (for it is the zooxanthellae that give coral their extraordinary colors). and eventually the coral died. Higher ocean temperatures have similarly resulted in algae losing their ability to photosynthesise (Kleypas and Yates, 2009) and rising sea levels, while not necessarily a problem for coral, as it is intuitively primed to respond by growing vertically, can cause it to drown if sea levels rise at rates faster than its ability to grow. Many Maldivian reefs are in this so-called catch up mode at present (Naseer, 2006). Unless checked, these changes could accumulate and result not only in the deaths of polyps and algae, reef systems and fish, but the entire Maldivian civilization (Naylor, 2015).

It is grazing fish, sea urchins and other organisms that transform coral into the sand and rubble that form islands in a coral aquapelago. They act as bio-eroders, grinding coral skeletons into fragments, digesting the algae they contain and excreting the ground coral (Johnson, 2014). This settles into the reef, forming a porous structure of coral fragments, shells, rubble and sand. This degraded coral debris is moved around by winds, waves, tides and currents. At times this process stabilises long enough to form sand bars that become vegetated to form islands; at others, the sand and rubble simply disappear back into the sea (Heyerdahl, 1986). What is land and what is sea is not fixed but changes all the time from day to day and season to season. "An atoll is not solid ground. It is not a constant thing in the way a rock island is a thing. An atoll is a not-so-solid eddy in a sea of sand and rubble" (Eschenbach, 2010). Coral islands are not islands in the ocean but islands of the ocean, produced by its dynamic energies. They are topological forms, liminal spaces, geology and 
Bremner: Aquapelago Concept/Maldives

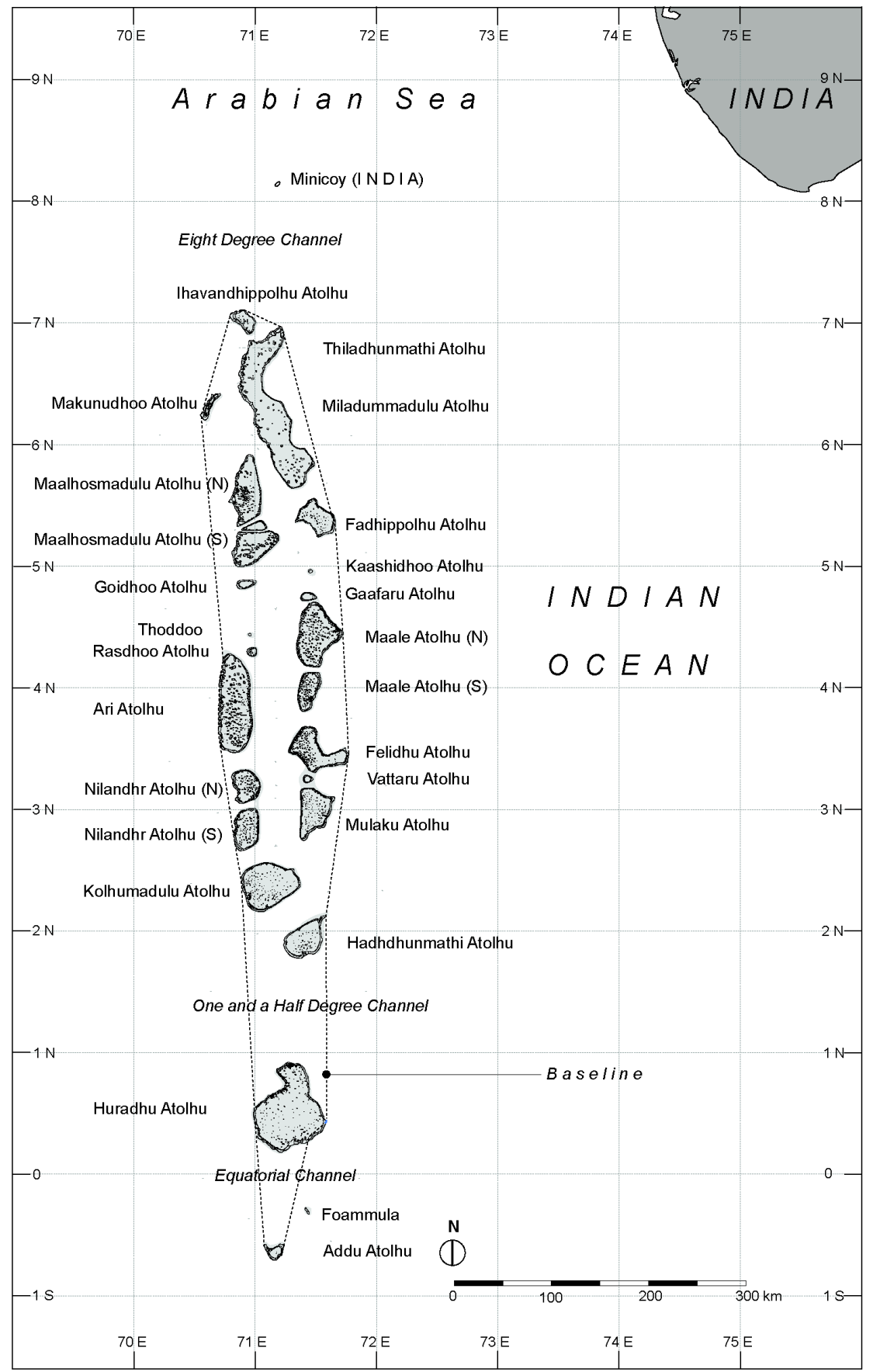

Figure 1 - Map showing the archipelagic baselines asserted by the Maldives (Office of Oceans Affairs US Department of State, 2005 - map drawn by the author and Ben Pollock.) 
biology, human and animal, land and sea. They are arrested matter in motion, driven by currents, tides, winds, seasons, and marine life. Islands, lagoons, mangrove swamps, sea grass beds and coral reef flats are little eddies of relative stability in a dynamic flow of relational instability. Landforms are sand-forms, relatively unstable, always moving, formed by erosion, deposition or siltation and shaped by the forces of seasonal monsoons.

\section{Living in a Coral Aquapelago}

My research found that living amongst these dynamic combinations of territorialised (relatively stabilised) and deterritorialised (relatively dynamic) elements in constant exchange, is integral to Maldivian culture and spatial practice and filled with real and imagined calamity. The nation's founding myth hinges on the story of a demon or jinni that lived in the sea. It came ashore once a month to visit an idol temple and demand the sacrifice of a young virgin. This continued until a pious Berber of Muslim faith arrived at the island on a voyage from North Africa and decided to put a stop to it. He hid in the temple in the place of the young virgin, and, reciting the Koran, succeeding in exorcising the jinni so that it never came back. According to ancient Maldivian writings, this is alledgedly why the Maldives accepted the Islamic faith and when the Maldivian nation was born (Heyerdahl, 1986).

As a buffer against such real and imagined threats that come from the sea, human settlements are traditionally located at the centre of islands surrounded by protective thickets of palms, mangroves and coastal scrub (Figure 2). Access to the sea is via two pathways through this vegetation, one to the east and one to the west. This enables boats to avoid the high winds and rough seas of the reversing monsoon and to access settlements safely year round and. A path connecting these two access points structures settlements axially, with mosques located at the centre on the highest ground. This spatial pattern embeds the ocean and its rhythms into the patterns of everyday life. Intimate terrestrial/marine knowledge is performed on a daily basis by Maldivian fishermen. Their unique pole-and-line fishing technique (Greenpeace, 2009: online) requires detailed knowledge of reefs, seabird movements and ocean currents and socialises the ocean with buoys and fish aggregating devices. Urban life in the Maldives is frequently lived between and among many islands, most being less than $1 \mathrm{sq} . \mathrm{km}$ in area. Male, the capital city, is itself an aquapelagic assemblage of urban infrastructure (suburbs, prisons, the airport, the oil depot, the waste dump etc.) spread across many small islands and the sea between (Figure 3). Boat and ferry journeys, often slow and rough, where duration is measured in time rather than distance, make the sea and its rhythms part of daily life and political struggle.

This way of living in and with rather than resisting atmospheric and oceanic energies was supported by a property regime that, until the island of Hulhumale was constructed (19972002) entertained no concept of private property or legal title to land (Naseer, 2007). The entire archipelago: its islands, reef flats, sandbanks, ocean floor, ocean volume and air space, were property of the state. Island chiefs allocated a plot of land to every male citizen over the age of eighteen on the island of their birth to live on. Uninhabited islands were communally held as varuuaa (which roughly translates as "for what it's worth islands"), allocated by atoll chiefs for the cultivation of coconut palms, the raising of crops or for firewood. No rent was charged for this and no standard regulations governed its practice. On some islands plots changed hands every year, whereas other islands were held as long 
as long as they were cultivated (Naseer, 2007). Island populations often abandoned their islands and took up residence on another in search of better water supplies or fishing grounds (Bluepeace Maldives, 2009). In such circumstances, evacuated islands were formally registered as Uninhabited Areas and handed back to the relevant government authority (Naseer, 2007). Supported by this fluid property regime, relocation was often the response to major oceanic disasters, such as the wash-overs that occurred in 1812, which forced the abandonment of twelve islands, in 1896-98, which temporarily submerged approximately half of Thulhaadhoo, and by the 2004 tsunami, which heavily damaged 13 islands, and displaced 10,530 people (Cazes-Duvat, 2005 in Naylor, 2015).

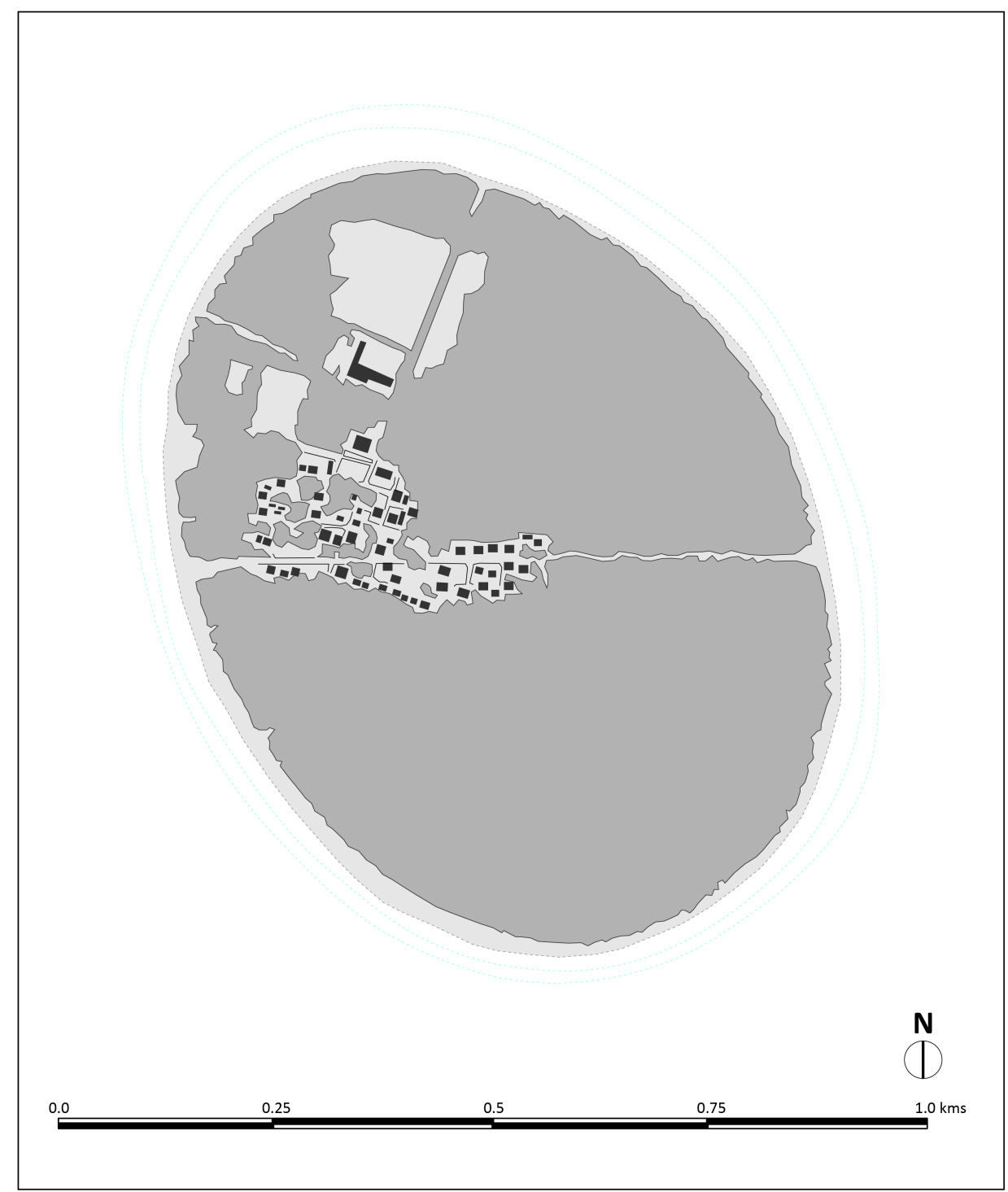

Figure 2 - Kumburudhoo, Haa Dhhaku Atoll, a small inhabited island with a population of 85 in 2006 (Atoll Images 2009). Map drawn by the author from Google Earth

\section{Shima Volume 11 Number 12017}

-22 - 


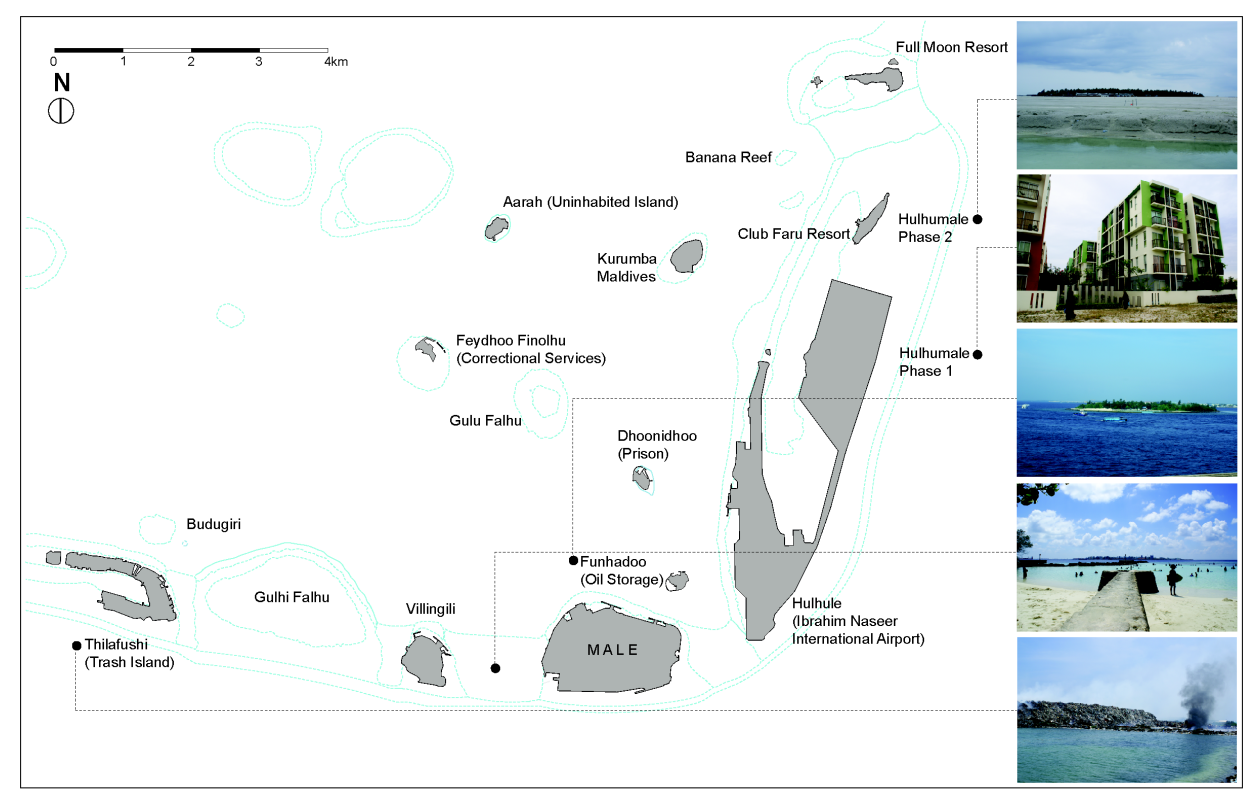

Figure 3 Map of Male, the capital of the Maldives, showing the assemblage of islands and the sea of which it is comprised. Map drawn by the author and Ben Pollock from Google Earth, photographs by the author.

In the 1970s, conception of the sea and relations with it began to change as its touristic potential was discovered. Marketing campaigns, tourist guides, and more recently Internet sites and social media began to perform the aquapelago in new ways by circulating its image as "nobody and nothing beyond each encircling beach" (Neville, 2012). The Maldives became synonymous with a pared-down aesthetic of palms, beach, sea, horizon and sky. In order to maintain this image, an entirely new infrastructure of engineering, technology, finance, education, legislation, global communication networks etc. were put to work. Taking advantage of the smallness of islands and their separation by relatively large distances of ocean, a unique Maldivian development model, the one-island-one-resort hotel was invented to capitalise the ocean for tourism against the backdrop of Islam. Its objective was to mediate and stabilise the dynamic relations of the aquapelago into what Mountz (2011: 118) calls an "enforcement archipelago" - a site for the creative exercise of power to quarantine tourists and local inhabitants from one another and to trap tourist dollars. From a spatial perspective this turned the traditional patterns of island settlement inside out (Figure 4). Instead of building inside a protective thicket of vegetation, hotel rooms and chalets were arrayed around the circumference of islands or splayed out over shallow reef flats to maximise the profit that could be squeezed from the sea. The two access pattern developed as a response to reversing monsoons was repurposed as a way of separating guest arrivals from services and deliveries. Elongated island tips and sandbanks, fluid from a hydrological perspective and therefore traditionally avoided, became prime spots for restaurants and bars. Recently, having exhausted the value relations of the overwater, resort developers began to explore the underwater as a new frontier of accumulation: underwater spas, restaurants and nightclubs began to offer new touristic experiences, not by providing more intimate experiences of the ocean, but putting it at a distance through layers of structural glass. 

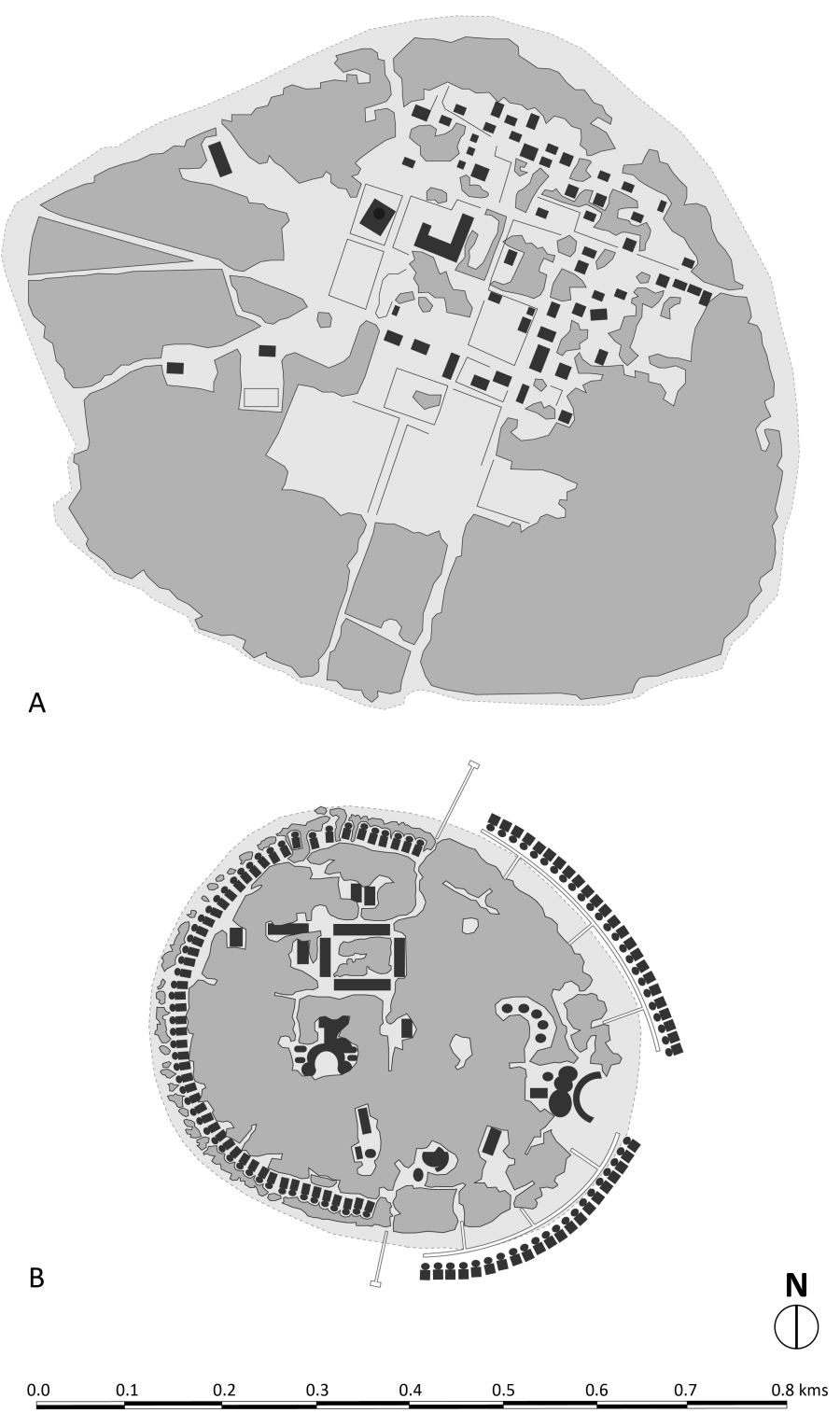

Figure 4 - Utheemu, Haa Alifu Atoll (A), a locally inhabited island compared with Alidhoo, Haa Alifu Atoll (B), a five star island resort (Atoll Images, 2009). Map drawn by the author from Google Earth.

In 1997 the Maldives government, in response to overcrowded conditions in Male brought about by the increasing disparities between it and other islands as a result of tourism, began an ambitious project to build a new island on the shallow reef flats of a lagoon $1.3 \mathrm{~km}$ north east of the capital city. This involved "borrowing" (ie dredging) sand and bleached, 
dead coral from a "borrow site" (Zahir and Sattar, 2015: 19, Figure 5), in this instance the western side of the Farukolhufushi lagoon, and depositing it on its eastern side. This produced two new topographies - a $1 \mathrm{~km}$ wide, $2.2 \mathrm{~km}$ long, $2 \mathrm{~m}$ high island and a $500 \mathrm{~m}$ wide, $2.2 \mathrm{~km}$ long, $8 \mathrm{o} \mathrm{m}$ deep subaquatic trench. A masterplan for the island's development was drawn up. Its planners paid little heed to traditional patterns of island settlement, instead arranging space by adopting an a-contextual New Urbanist formula of axial spines, green strips, walkable streets and economic zones and districts (Figure 6). When questioned about this at a symposium in Male in November 2015, a Maldivian architect said "Well, in terms of context, there is not much to relate to!" It is as if architects are blind to the ocean, and not surprising that the 2004 tsunami washed over this arrangement with little resistance, returning considerable amounts of the borrowed sand to the sea.

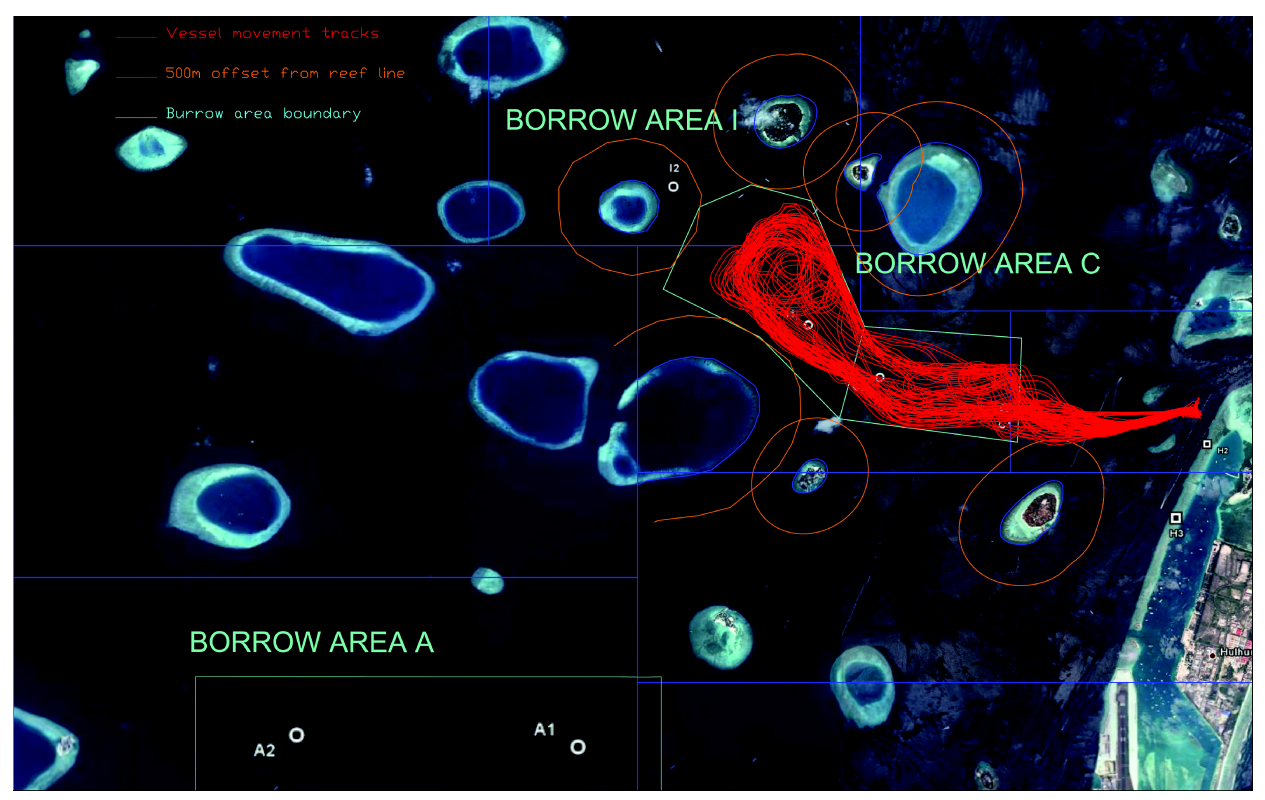

Figure 5 - This image shows the extent of dredging operations for Hulhumale Phase 2 for one week. Source: Zahir and Sattar (2015), courtesy Housing Development Corporation Ltd.

This experiment in appropriating and rearranging the ocean floor required advanced instruments of measurement and mapping, sophisticated dredging and levelling equipment, defensive infrastructures (geotubes, rocks, precast concrete walls etc.) to hold it in place and a plethora of textual and visual rhetorics (scale models, graphic fly-throughs etc.) to market the precarious development as a global investment opportunity. Significantly, Hulhumale was the first island where Maldivians could buy and sell property, amounting, as a disgruntled Maldivian put it, to "basically selling the sea" (Naish, 2015). Property relations, traditionally centred on the island chief, were put under the authority of a state owned enterprise, the Housing Development Corporation Ltd. (HDC). This operates as master developer, contractor for infrastructure, utilities and services, as regulator of planning and building codes and it leases and sells land and property (Housing Development Corporation Ltd., 2016). This managerial approach to urban life and space undercut previous ways of organising human relations, causing a café owner to complain "In Hulhumale, we have only one problem: nobody is responsible for these islanders. On

\section{Shima Volume 11 Number 12017}


Male and other islands, there are island chiefs. But here we have only the HDC" (Luxner, 2009). Property ownership also radically transformed people's way of dealing with risk. Instead of the guaranteed custodianship of the state, property ownership privatised risk and transformed it into surplus value. There are now two Maldivian insurance companies offering home insurance in the Maldives: Allied Insurance, set up as a joint venture between Commercial Union Assurance UK and the Maldives State Trading Company in 1985, and Amana Takaful Maldives, which began operating in 2003.

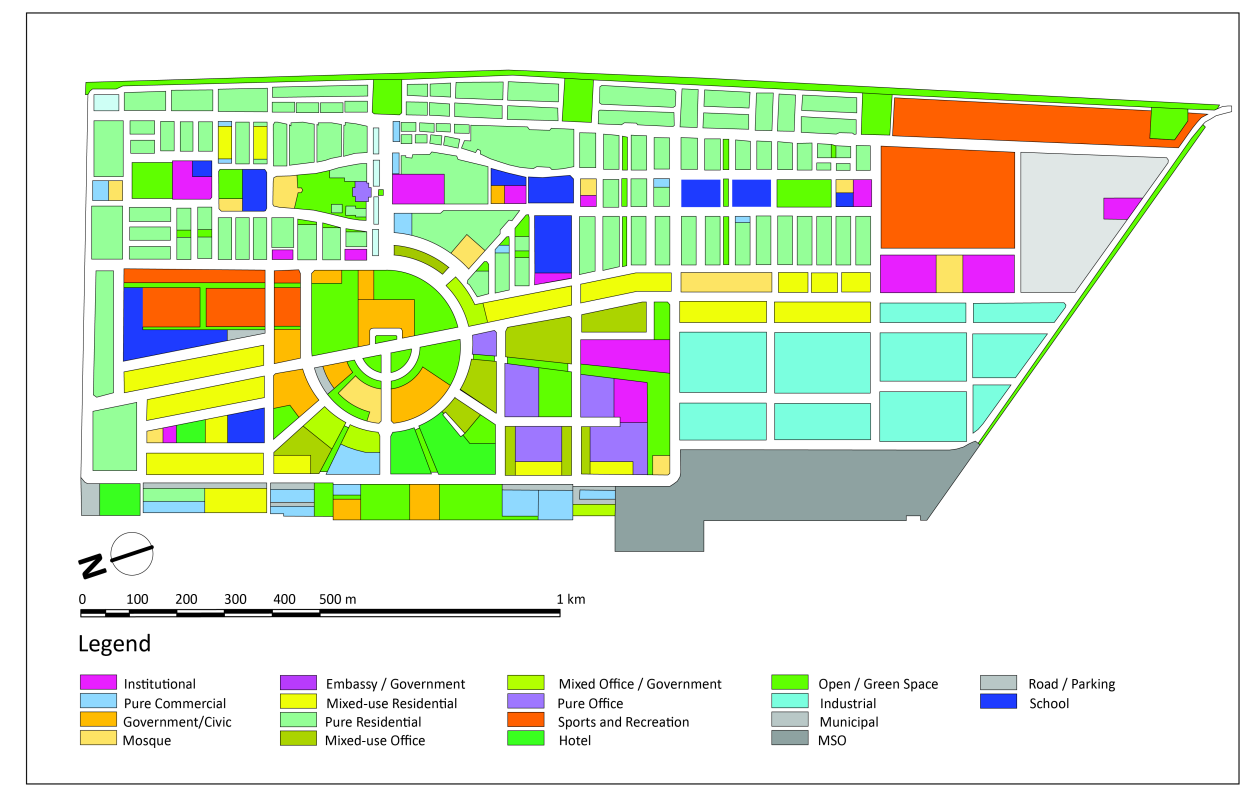

Figure 6 - Hulhumale Phase 1 Land Use Plan as represented on the website of the Housing Development Corporation Ltd. (2016). Map drawn by the author, courtesy Housing Development Corporation Ltd.

Since the advent of tourism then, as the technologies and infrastructures to capitalise it were put in place, the ocean became not less, but more enmeshed in human affairs by becoming more economically, technologically and digitally mediated. New aquapelagic performances combining infrastructures, technologies and global imaginaries produced new species of islands, new kinds of oceans, new typologies of architecture and new kinds of humans, constantly reassembling the unstable continuum between geological, hydrological, human, animal and technological life according to the laws of value.

All this and more besides is evidence of aquapelagic environment in which the ocean is not void, valueless, neutral or smooth, but a highly articulated polity (Dawson, 2012). No event expressed this more potently than the underwater cabinet meeting staged by former President Nasheed in 2009 to sign a document calling for global cuts in carbon emissions and draw attention to the vulnerability of his nation to sea level rise. In video footage of the event, we hear Nasheed and his cabinet breathing slowly through oxygen masks, and see them communicating using hand signals and white boards. They awkwardly sign the climate change document at desks propped on the seabed witnessed by reef fish and snorkeling journalists, diving instructors and military personnel (BBC News, 2009). This

\section{Shima Volume 11 Number 12017


somewhat incongruous event transformed the oceanic volume into a council chamber and aligned human experiences of the ocean with geo-politics. It emphasised that despite the continuum of land-sea relations in an aquapelago (Suwa, 2012), water is not air, and reminded the world that sea level rise will be climate genocide.

\section{BIBLIOGRAPHY}

Atoll Images (2009) Above Maldive, Male: Atoll Images

BBC News (2009) 'Maldives Cabinet Makes a Splash', October 17th: http://news.bbc.co.uk/1/hi/8311838.stm - accessed February 9th 2017

Bluepeace Maldives (2009) 'Dhuvaafaru: One of the Most Vulnerable Islands to Climate Change', Bluepeace Blog February 28th: http://www.bluepeacemaldives.org/blog/climatechange/dhuvaafaru-vulnerable-to-climate-change - accessed February 9 th 2017

Bremner, L (2016) 'Thinking Architecture with an Indian Ocean Aquapelago', GeoHumanities v2 n2: 284-310

Cazes-Duvat, V (2005) 'Les archipels de l'ouest de l'océan indien face à l'érosion cotière (Mascareignes, Seychelles, Maldives)', Annales de Géographie v114 n644:342-361

Chancellor, G (2008) 'Introduction to Coral Reefs', Darwin Online: http://darwinonline.org.uk/EditorialIntroductions/Chancellor_CoralReefs.html - accessed February 9th 2017

Darwin, C (1842) The Structure and Distribution of Coral Reefs, London: Smith Elder and Co

Dawson, H (2012) 'Archeology, Aquapelagos and Island Studies', Shima v6 n1: 17-21

Eschenbach, W (2010) 'Floating Islands', Watts Up With That? January 27th: http://wattsupwiththat.com/2010/o1/27/floating-islands/ - accessed February 9th 2017

Greenpeace (2009) 'Catching Tuna Maldivian Style', You Tube, January 29th: https://www.youtube.com/watch?v=HP6rYThJWUg\&t=86s - accessed February 9th 2017

Hau'ofa, E (1993) 'Our Sea of Islands', in Waddell, E, Naidu, V and Hau'ofa, E (eds) A New Oceania: Rediscovering Our Sea of Islands, Suva, Fiji: University of the South Pacific: 2-16

Hayward, P (2012a) ‘Aquapelagos and Aquapelagic Assemblages', Shima v6 nı: 1-11

----- (2012b) 'The Constitution of Assemblages and the Aquapelagality of Haida Gwaii', Shima v6 n2: 1-14

Heyerdahl, T (1986) Maldive Mystery, New York: George Allen and Unwin

Housing Development Corporation Ltd (2016): http://hdc.com.mv/ - accessed February 9th 2017

\section{Shima Volume 11 Number 12017}

- 27 - 
Intergovernmental Panel on Climate Change (2001) IPCC Third Assessment Report: http://www.grida.no/publications/other/ipcc_tar/?src=/climate/ipcc_tar/ - accessed February 9 th 2016

Kleypas, J and Yates, K (2009) 'Coral Reefs and Ocean Acidification', Special Issue Feature, Oceanography: http://coralreef.noaa.gov/education/oa/resources/22-4_kleypas.pdf accessed February 9 th 2017

Latour, B (2004) Politics of Nature, Cambridge: Harvard University Press

Luxner, L (2009) 'Raising the Maldives - Saudi Aramco World: Arab and Islamic Cultures and Connections':

http://archive.aramcoworld.com/issue/young.readers.world/raising.the.maldives/default.ht m - accessed February 2016

Mountz, E (2011) 'The Enforcement Archipelago: Detention, haunting, and asylum on islands', Political Geography v30: 118-128

Naish, A (2015) 'Majlis Approves Foreign Freeholds in Second Amendment to Constitution', Minivian News July 22nd: http://minivannewsarchive.com/politics/majlis-authorizesforeign-ownership-of-land-in-second-constitutional-amendment-101193 - accessed February 9th 2016

Naseer, A (1997) 'Profile and Status of Coral Reefs in Maldives and Approaches to Its Management': http://www.fao.org/docrep/x5627e/x5627eoa.htm - accessed February 9th 2016

----- (2006) 'Vulnerability and Adaption Assessment of the Maldives Coral Reefs,' Technical Paper for the Maldives

National Adaptation Plan of Action for Climate Change, Male: Ministry of Environment, Energy and Water (2007) 'Pre-and post-tsunami coastal planning and land-use policies and issues on the Maldives' in Broadhead, J and Leslie, R (eds) Proceedings of the Workshop on Coastal Area Planning and Management in Asian Tsunami-Affected Countries, Bangkok: Food and Agriculture Organization of the United Nations Regional Office for Asian and the Pacific: 147-63: http://www.fao.org/docrep/o10/ag124e/AG124Eog.htm - accessed February 9th 2016

Naylor, A.K (2015) 'Island Morphology, Reef Resources, and Development Paths in the Maldives', Progress in Physical Geography v39 n6: 728-749

Neville, A (2012) 'The History of Tourism in the Maldives', The Telegraph, Travel, November 23rd: $\quad$ http://www.telegraph.co.uk/luxury/travel/3049/the-history-of-tourism-in-themaldives.html - accessed February 9th 2017

Office of Oceans Affairs, US Department of State (2005) 'Limits in the Seas nı26 - Maldives Maritime Claims and Boundaries':

http://www.state.gov/documents/organization/57678.pdf - accessed February 9th 2017

Pearson, M (2003) The Indian Ocean, London: Routledge

\author{
Shima Volume 11 Number 12017
}

-28 - 
Bremner: Aquapelago Concept/Maldives

Suwa, J (2012) 'Shima and Aquapelagic Assemblages', Shima v6 n1: 12-16

Zahir, H and Sattar, S (2015) 'Weekly Monitoring Report, 2nd week of February 2015', EIA Report for Hulhumale 2nd Phase Reclamation and Hulhumale Harbor and Quay Wall Project http://www.epa.gov.mv/ - accessed February 9th 2017 